\title{
MEMAHAMI KEBIJAKAN EKONOMI POLITIK TIGA KHALIFAH (Sebuah Kajian Historis Tiga Fase Peradaban Islam)
}

\author{
Ayief Fathurrahman \\ Universitas Muhammadiyah Yogyakarta \\ e-mail: ayief_ospp@yahoo.com
}

\begin{abstract}
One thing that needs to be understood is that every result of human thought is always historical, tied to the space and time around it. The economic policies issued by Umar ibn Khattāb, Umar ibn Abdul Aziz and Ghazan Khan must have certain truths in accordance with the dimensions of space and the cycle of time. However, the form of policy is an effort to solve the problems of the State, especially the economic sector that occurred in the middle of their leadership period. This article aims to examine the political economic thought of three caliphs, namely Umar ibn Khattāb, Umar ibn Abdul Aziz, and Ghazan Khan with a historical approach. Political economic policy decided by Umar ibn Khattāb, Umar ibn Abdul Aziz, and Ghazan Khan has a character that is flexible. It means however its method, during its goal to create welfare for the people and not in conflict with al-Quran and al-Sunnah, then that policy is applied. This was apparent when some of their policies are not always same as Prophet's policy, even differ from each other, but with that difference, the world has recorded them as a brilliant decision maker. The policy of the three caliphs teaches us the ultimate determinants of the economic policy of the meaning of welfare (maslahah) which form the basis of the formulation of one policy. Rigid economic system will only become a separate boomerang for economic growth itself. Because the true that the holy economic goal is not economic growth, but the welfare of mankind as perpetrators of economic activity in this hemisphere.
\end{abstract}

Keywords: Islam, Economic-Politics, Flexible, Welfare

\section{Pendahuluan}

Peradaban suatu bangsa pasti tidak akan pernah terlepas dari kebijakan yang ada pada bangsa itu sendiri. Kerapkali kemunduran bahkan kehancuran suatu bangsa bermula dari salah kaprahnya kebijakan yang diterapkan. Namun tak jarang juga, arus kemajuan dan kejayaan suatu bangsa bermuara dari kebijakan. Kebijakan sangat menentukan haluan suatu bangsa, ke mana nohkoda bangsa hendak berlayar. Oleh karena itu, kebijakan merupakan hal yang sangat esensial dalam menentukan pengembangan sebuah bangsa dalam rangka membangun satu peradaban dan menorehkan kemajuan. Pendek kata, maju mundurnya suatu bangsa sangat tergantung pada kebijakan yang diterapkan.

Sebagai terminal akhir suatu kebijakan, maka kemampuan seorang pemimpin sangat menentukan. Tercatat dalam lembaran sejarah, Islam pernah memiliki pemimpin-pemimpin (khalifah) yang namanya masih acapkali dibicarakan, baik di kalangan akademisi maupun non-akademisi, bahkan menjadi rujukan dalam memformulasikan suatu tindakan berupa kebijakan yang menyentuh wilayah politik, sosial, dan ekonomi.

Di tangan merekalah kejayaan Islam pernah diraih. Kala itu, kemajuan Islam sungguh berada pada puncaknya, baik dari aspek politik, sosial, ekonomi dan budaya. Kemajuan di 
bidang politik dibuktikan dengan meluasnya ekspansi Islam ke berbagai negara sekitarnya. Kekuatan politik menyumbang dampak positif tehadap kesejahteraan sosial masyarakat, dengan diterapkannya berbagai kebijakan berdasarkan dengan tuntutan realitas dan kesejahteraan dan berlandaskan perintah yang termaktub dalam al-Quran dan al-Sunnah.

Umar ibn Khattab adalah salah satu khalifah yang pernah menorehkan tinta emas pada lembaran sejarah peradaban umat Islam. Pada masanya, pemerintahan Islam semakin kuat, yang didukung dengan formulasi kebijakan yang sangat fenomenal. Banyak perubahan yang dilakukan, bukan saja di ranah ritual keagamaan, tetapi juga meliputi aspek sosial budaya, politik dan terutama pada ranah kebijakan ekonomi.

Selain itu, pada masa Dinasti Umayyah, tampuk kejayaan seringkali dinisbatkan kepada Khalifah Umar ibn Abdul Aziz. Pada masanya, urusan dalam negeri sangatlah diprioritaskan, terutama menjamin keamanan rakyat dan mengkomodir semua aspirasi golongan. ${ }^{1}$ Pada masanya juga, pertumbuhan perekonomian negara sangat meningkat, bahkan mampu menapak defisit anggaran APBN yang diwariskan oleh pemerintahan sebelumnya. Hal demikian, tentu saja selain faktor keamanan, juga banyak faktor yang melatarbelakangi pertumbuhan ekonomi tersebut, termasuk ranah kebijakan yang diterapkan.

Enam ratusan tahun berlalu setelah Khalifah Umar ibn Abdul Aziz, muncullah pemimpin muslim berdarah Mongol yang bernama Ghazan Khan (1295-1304). Semenjak di bawah kepemimpinannya, walaupun relatif singkat hanya sembilan tahun berkuasa, Dinasti Ilkhan mencapai kemajuan yang luar biasa. Hal ini dibuktikan dengan banyaknya kepala negara yang berdatangan ke istananya di Tabriz. ${ }^{2}$ Pada masanya, pertumbuhan ekonomi sangat signifikan, terutama perekonomian rakyat kecil dan menengah, sehingga membuahkan hasil kesejahteraan yang patut untuk diteladani.

Tiga pemimpim (khalifah) di atas telah memberikan pelajaran yang sangat berharga, melalui kebijakan-kebijakan yang telah diterapkan pada masing-masing masanya, khususnya kebijakan di bidang ekonomi politik, sehingga pada gilirannya mampu melahirkan kesejahteraan dan kemakmuran bagi rakyat.

Dari sini, penulis bermaksud untuk menggali lebih dalam dasar pemikiran-pemikiran tersebut dan berupaya mempertemukan titik benang merahnya, dengan harapan bisa menjadi acuan ataupun kaca perbandingan terhadap perkembangan ekonomi Islam saat ini.

\section{Kebijakan Ekonomi Politik Umar Ibn Khattab}

Agenda pertama setelah Umar memegang amanah jabatan sebagai khalifah adalah ekspansi wilayah Islam sebagai kelanjutan dari kebijakan Khalifah Abu Bakar. ${ }^{3}$ Dengan demikian, pada masa kepemimpinannya, daerah taklukan Islam meluas hingga Jazirah Arabia, Palestina, Syria, Mesir, dan sebagian besar wilayah Persia. ${ }^{4}$ Meluasnya ekspansi yang tengah

\footnotetext{
${ }^{1}$ M. Abdul Karim, Sejarah Pemikiran dan Peradaban Islam (Yogyakarta: Pustaka Book Publisher, 2007), 124.

${ }^{2}$ M. Abdul Karim, Islam di Asia Tengah: Sejarah Dinasti Mongol-Islam (Yogyakarta: Bagaskara, 2006), 92.

${ }^{3}$ Ada beberapa sebab ekspansi Umar ibn Khattab di antaranya adalah letak geografisnya merupakan wilayah perbatasan dengan wilayah Islam, dan sejak awal memiliki hubungan kurang harmonis dengan bangsa Arab; utusan Nabi dibunuh orang Kristen di Syiria atas restu Raja Heraklitus. Lebih lanjut baca M. Abdul Karim, Sejarah Pemikiran, 85.

${ }^{4}$ Harun Nasution, Islam Ditinjau dari Berbagai Aspeknya, jilid 1, cet. kelima (Jakarta: UI Press, 1985), 58.
} 
dilakukan, mau tidak mau menuntut Umar untuk mengatur administrasi negara yang terencana. $^{5}$

Di samping itu, ekspansi wilayah menyebabkan pendapatan negara mengalami peningkatan yang sangat berarti. Dalam rangka mengelola pendapatan tersebut, setelah bermusyawarah dengan sahabat lain, maka Umar mengeluarkan kebijakan agar pendapatan yang menjadi kas negara tersebut dikelola dengan terencana dan terarah. ${ }^{6}$ Lembaga Baitul Mal yang telah dicetuskan pada masa Rasulullah, menjadi institusi yang memiliki peran penting pada masanya dalam rangka mengelola tata kelola keuangan negara. ${ }^{7}$

Sebagai khalifah, Umar ibn Khattab sangat memperhatikan kemaslahatan bersama secara profesional. Hal ini dibuktikan dengan berbagai rumusan kebijakan yang penuh dengan pertimbangan dan pemikiran yang mendalam. Sehingga, zamannya dikenal dengan zaman yang sarat dengan perubahan, dan tak jarang kebijakannya berbeda dengan kebijakan Rasulullah.

Kebijakan yang paling fenomenal adalah kebijakan fiskal di sektor perpajakan tentang pertanahan dan pertahanan, atau sering kali juga dikenal dengan kebijakan Umar di Sawad (tanah subur). Umar memutuskan untuk tidak mengambil alih tanah taklukan, namun justru diberikan pengelolaan sepenuhnya kepada pemiliknya, namun diwajibkan membayar pajak (kharaj) sebesar 50 persen dari hasil panen. ${ }^{8}$

Ada beberapa alasan kebijakan ini lebih disukai oleh Umar, antara lain andaikata tanah taklukan itu diambil alih oleh negara, maka secara otomatis para pasukan (tentara) Islam yang akan mengelolanya, padahal menurut Umar, para tentara bukanlah ahli bercocok tanam, selain kualitas pertanian akan menurun, juga akan berdampak pada rendahnya produktivitas. Selain itu, pendapatan negara melalui pajak akan jauh menurun, mengingat pajak (kharäj) bagi nonmusim sebesar 50\% dan pajak (uSr) bagi bagi muslim hanya $10 \%$ saja. Di samping itu, hal yang sangat dipertimbangkan oleh Umar adalah kekhawatiran akan adanya gelombang pemberontakan, ${ }^{9}$ sebagai dampak pengangguran dan kemiskinan. Sehingga pada gilirannya akan memberikan angin negatif tersendiri bagi keamanan dan keutuhan negara.

Pada kebijakan pertahanan, dalam rangka menanggung nasib para tentara, maka pada zaman Umar lah awal mula ditetapkan gaji tetap bagi para tentara, selain sebagai tujuan untuk memenuhi kebutuhan hidup, juga agar terjaga motivasi para tentara dalam membela negara. ${ }^{10}$ Selain itu, ketika Umar melihat bahwa kebijakan bea cukai yang merugikan satu pihak, ${ }^{11}$

\footnotetext{
${ }^{5}$ Administrasi negara dibagi ke beberapa wilayah provinsi: Makkah, Madinah, Syiria, Jazirah, Basrah, Kufah, Palestina, dan Mesir. Baca lebih lanjut Badri Yatim, Sejarah Peradaban Islam: Dirasah Islamiyah II (Jakarta: PT Raja Grafindo Persada, 2003), 37.

${ }^{6}$ Adiwarman Azwar Karim, Sejarah Pemikiran Ekonomi Islam, edisi ketiga (Jakarta: PT Raja Grafindo Persada, 2004), 59.

${ }^{7}$ Dalam lembaran sejarah, pendirian Baitul Mal dilatarbelakangi oleh kedatangan Abu Hurairah yang kala itu menjabat sebagai Gubernur Bahrain dengan membawa harta hasil pengumpulan pajak kharāj sebesar 500.000 dirham pada tahun 16 Hijriah.

8 Sistem ini pada zaman Dinasti Abbasiah, khususnya periode Harun al-Rashid, dikenal dengan sebutan muqāsamah, pengertiannya adalah negara mengambil bagian dari hasil pertanian dari para penggarapnya.

${ }_{9}^{9}$ M. Abdul Karim, Sejarah Pemikiran, 87.

${ }^{10}$ Ali Isamer, Ittihash (Dhaka: Ali Publication, 1976), 206-210.

${ }^{11}$ Pada masa Rasulullah, kebijakan bea cukai telah ditiadakan. Namun pada masa Umar diterapkan kembali, hal ini berawal dari orang-orang Harbi yang mewajibkan para pedagang muslim bayar pajak ketika berdagang di tanah Harbi (Hierapolis), sehingga melihat ketidakadilan tersebut, maka Umar pun menerapkan kebijkan yang sama.
} 
terutama negara Islam, maka Umar pun menerapkan wajib pajak bagi siapa saja dari warga asing non-muslim yang hendak memasuki wilayah teritorial Islam untuk berdagang sebesar $10 \%$ dari barang yang dijual, sementara bagi dhimmi yang berada dalam kekuasaan Islam dikenakan sebesar 5\%, dan muslim 2,5\% dari harga barang dagangan. ${ }^{12}$

Hal lain dari kebijakan ekonomi Umar yang menarik untuk dikaji adalah tentang perpajakan kuda. Pada masa pemerintahan Umar, bisnis perdagangan kuda semakin merebak, bahkan pernah diriwayatkan pernah ada seekor kuda Arab Taghlabi yang diperkirakan bernilai 20.000 dirham. ${ }^{13}$ Sehingga melihat keadaan demikian, maka Umar menarik zakat dari bisnis perdagangan kuda tersebut dan membagikannya kepada orang-orang miskin dan para budak. ${ }^{14}$

Berkaitan dengan segelintir kebijakan ekonomi Umar sebagaimana dijelaskan di atas, ada satu hal yang mesti digarisbawahi, yaitu mengenai pendistribusian kas Baitul Mal sebagai tunjangan sosial kepada kerabat Rasulullah dan orang-orang yang berjasa dalam membela Islam. $^{15}$ Karena dibalik niat yang mulia itu ternyata menuai kritikan dari salah seorang sahabat, Hakim ibn Hizam. Menurutnya, hal demikian akan mendongkrak mereka dengan sifat malas, dan akan menjadi fatal ketika pemerintah sudah tidak lagi menerapkan kebijakan tersebut. ${ }^{16}$ Khalifah menyadari bahwa kebijakan tersebut mengandung kekeliruan dan berimbas negatif terhadap strata sosial masyarakat dan berniat untuk memperbaikinya. Namun Umar wafat sebelum terealisasikan rencananya. ${ }^{17}$

Dari berbagai kebijakan ekonomi Umar ibn Khattab tersebut, nampak Khalifah Umar tidak terlalu memprioritaskan kaum miskin di atas kaum kaya ataupun sebaliknya, tetapi Umar lebih mengedepankan kemaslahatan bersama. Setiap kebijakan selalu berupaya untuk menjawab keadaan realitas dengan tidak memberatkan dalam implemenatasinya. Sehingga dengan demikian, dapat dikatakan fleksibilitas menjadi karakteristik perekonomian di masa Umar ibn Khattab. Kebijakan ekonomi yang kaku sangat dihindari oleh Umar karena akan berdampak negatif terhadap bangunan kemaslahatan yang ingin dicapai. ${ }^{18}$ Kemaslahatan menjadi dasar ataupun landasan bagi Umar dalam menjalankan roda perekonomian, sebagai sebuah pengejewantahan dari perintah yang termaktub dalam al-Quran dan al-Sunnah.

Demikianlah Umar ibn Khattab yang terkadang melakukan ta'Til (mencari alasan rasional dari suatu hukum). Karena dalam urusan muamalah yang menjadi pertimbangan utama adalah asas manfaat bagi masyarakat. Inilah konsep raḥmatan li al- 'ālamīn, membawa rahmat bagi semesta alam.

\footnotetext{
${ }^{12}$ Husaini S. A.Q. Arab Adminitration (Madras: Soldent \& Co., 1949), 47-48.

${ }^{13}$ Adiwarman Azwar Karim, Sejarah Pemikiran Ekonomi, 69.

14 Pada masa Rasulullah, zakat atas kuda belum diwajibkan karena memang jumlahnya sangat terbatas, dan bukan untuk dikomersialisasikan, tapi digunakan sebagai fasilitas perang.

${ }^{15}$ Para Sejarawan meyakini bahwa tindakan Umar demikian adalah tidak lain dan tidak bukan sebagai pemberian tanda jasa kepada relawan yang telah gigih berjuang membela dan meneggakan agama Islam di awal kehadirannya.

${ }^{16}$ Adiwarman Azwar Karim, Sejarah Pemikiran Ekonomi, 64.

17 Afzalurrahman, Doktrin Ekonomi Islam, Jilid 1 (Yogyakarta: PT Dhana Bakti Wakaf, 1995), 165.

${ }^{18}$ Qutbh Ibrahim Muhammad, Kebijakan EkonomiUmar ibn Khattab (Jakarta: Pustaka Azam, 2002), 225.
} 


\section{Kebijakan Ekonomi Politik Umar Ibn Abdul Aziz}

Di persimpangan catatan sejarah Dinasti Ummayah yang menampilkan ketidakberesan dalam segala aspek politik, sosial, dan ekonomi, sebagai dampak dari pola hidup kaum feodal istana yang serakah, terpilihlah Umar ibn Abdul Aziz sebagai khalifah. Terpilihnya Umar ibn Abdul Aziz sebagai khalifah ibarat sang pencerah yang mencerahkan ketika para khalifah Dinasti Ummayah gemerlap dengan kekuasaan. Keadaan ini dapat dilukiskan dengan ucapannya, "innā lillāhi wa innā ilaihi rāji'ūn", ${ }^{19}$ yang seolah menggambarkan betapa beratnya keadaan yang harus diubah sebagai tanggung jawab seorang khalifah. ${ }^{20}$ Namun, sebagai bukti awal dan tekad yang bulat untuk mengembalikan kesejahteraan rakyat yang dirampas oleh kaum feodal, maka seluruh hartanya, ia kembalikan ke kas negara. ${ }^{21}$

Untuk mengawali pembangunan kembali pondasi negara, maka penjabat-penjabat pemerintah yang menjadi biang keladi penggembosan lumbung kekuatan negara diamankan setimpal dengan tindak pidana yang telah diputuskan. Pada masanya, keadilan benar-benar ditegakkan, para penjabat yang korup dan mengabaikan hak-hak rakyat dipecat tanpa kompromi. Gerakan "sapu bersih" di lingkungan pemerintahan ini menjadi basis awal pembangunan fundamental ekonomi negara yang sustainable. Faktor inilah, menurut Umar penyebab instabilitas perekonomian negara yang harus dihilangkan. Andaikata kebijakan tersebut tidak langsung diterapkan segera, mungkin Umar ibn Abdul Aziz merupakan khalifah yang terakhir Dinasti Ummayah, mengingat kesejahteraan sudah tidak lagi dirasakan oleh rakyat dan suburnya gerakan bawah tanah yang hendak menggulingkan pemerintah. Oleh kerana itu, pada masanya, urusan dalam negeri sangatlah diprioritaskan, terutama menjamin keamanan rakyat dan mengakomodir semua aspirasi golongan.

Menyadari akan ketidakadilan kaum feodal istana terhadap kehidupan rakyat kecil, terutama dengan kepincangan masalah perpajakan, yang mana pada waktu itu banyak para pejabat yang tidak membayar pajak, akan tetapi rakyat kecil lah yang dikenai pajak yang melampui batas. Maka Umar mereformasi sistem perpajakan agar menjadi adil dalam pemasukan anggaran negara. ${ }^{22}$

Dalam rangka pemulihan dari terpaan badai krisis ekonomi yang melanda negeri kala itu, sebagai imbas dari sistem yang tidak berkeadilan dari para penjabat pendahulunya, maka langkah yang diambil Umar adalah berupa bentuk penghematan anggaran dalam pemberian fasilitas pejabat negara dan juga penghematan dalam perayaan peringatan hari besar keagamaan dan kenegaraan. ${ }^{23}$ Umar menyadari bahwa kebijakan pengelolaan anggaran merupakan bagian dari kebijakan fiskal yang terpenting selain pajak.

Penyusunan anggaran yang efesien sangat penting karena keterkaitannya dengan berbagai sektor perekonomian. Kontribusinya yang besar tidak hanya dalam mendorong

\footnotetext{
${ }^{19}$ M. Abdul Karim, Sejarah Pemikiran, 123.

${ }^{20}$ Umar juga menyadari bahwa dia juga bagian dari permasalahan itu di masa lalu yang hidup di lautan gemerlapnya kemewahan istana, bahkan dijelaskan dalam satu riwayat, sebelum menjabat khalifah, Umar sering terlambat shalat ke masjid karena pembantunya lambat menyisir rambutnya, namun ketika menjabat khalifah, terlambat datang ke masjid di hari Jum'at, karena pakaian satu-satunya yang bertempelan jahitan lebih dari 100 tambalan belum kering.

${ }^{21}$ M. Abdul Karim, Sejarah Pemikiran, 123.

22 Latif Hakim, "Strategi Umar Ibn Abdul Aziz dalam Mengentaskan Kemiskinan", dikutip dari http://zulfikri.wordpress.com/2007/08/26/strategi-umar-ibn-abdul-aziz-dalam-mengentaskan-kemiskinan/.

23 Ibid.
} 
pertumbuhan ekonomi, tetapi juga dalam pengurangan penduduk miskin dan menciptakan stabilitas ekonomi serta meningkatkan pendapatan per kapita. ${ }^{24}$ Dengan kata lain, tujuan dari adanya penghematan di dalam pengelolaan anggaran adalah menopang tujuan pokok dari setiap pemerintahan Islam berupa kesejehateraan bagi seluruh warga negera.

Kesejahteraan umat menjadi kata kunci dalam penentuan kebijakan ekonomi Umar, sehingga dalam mengatasi berbagai persoalan dalam bidang ekonomi, kesejahteraan menjadi tujuan. ${ }^{25}$ Dengan demikian, kebijakan ekonomi Umar terlihat tidak terlalu kaku dan tekstual, tapi justru berupaya untuk mengejewantahkan nilai-nilai islami dalam menghadapi realitas dan kenyataan.

Fleksibelitas kebijakan ekonomi Umar ibn Abdul Aziz sangat terlihat ketika mencabut kewajiban kharāj dan jizyah bagi orang-orang non-muslim. Menurutnya, bahwa Nabi diutus ke dunia bukan untuk mencari harta dan mencari pajak, namun justru mengislamkannya. ${ }^{26}$ Tetapi kemudian setelah melihat realita, bahwa terjadi tekanan ekonomi yang sangat serius, maka Umar mengeluarkan dekrit untuk kembali ke kebijakan lama, yaitu kebijakan yang dikeluarkan oleh Umar ibn Khattab, yaitu "kebijakan ekonomi di Sawad" dengan memberlakukan kembali penerapan jizyah dan kharäj bagi dhimmi petani dan tuan tanah untuk keselamatan jiwa dan tanah mereka. ${ }^{27}$

Akan tetapi setelah kemudian hari banyak dhimmi yang masuk Islam hanya karena menghindari kharāj. Akibatnya, negara mengalami instabilitas ekonomi yang kuat. Dalam rangka menanggulangi masalah tersebut, setelah bermusyawarah dengan para ekonom dan ulama, maka Umar mengeluarkan dekrit, bahwa orang muslim selama ini yang menikamati tanah kharāj membayar pajak sebagai tanah uṣr mulai pada $100 \mathrm{H}$, dilarang jual beli tanah. Dengan demikian, keputusan ini membawa arti bahwa apabila seorang muslim betul-betul masuk Islam, ia harus tinggalkan sawahnya dan digarap petani tetangga yang non-Islam, dia diberi gaji pensiun tiap bulan oleh negara atau ia boleh menggarap sawah sendiri, tapi ia harus bayar kharäj. ${ }^{28}$ Dengan melakukan restrukturisasi organisasi negara, dan penghematan anggaran belanja negara. Maka, dengan cara begitu Umar dapat memaksimalkan sumbersumber pendapatan negara melalui zakat, pajak dan jizyah.

Pengalokasian subsidi ke masyarakat yang berdaya beli rendah sebagai tujuan distribusi zakat, terus ditingkatkan pada masanya. Umar menyadari bahwa zakat merupakan sebuah instrumen pertumbuhan ekonomi dan pemerataan pembangunan ( growth dan equity). ${ }^{29}$ Dari sinilah terlihat konsep demokrasi ekonomi Umar yang tidak harus diartikan sebagai berlakunya prinsip equal treatment (perlakuan sama), tetapi ada orang yang tidak berpunya perlu memperoleh pemihakan dan bantuan yang berbeda (partial treatment). ${ }^{30}$ Sehingga

\footnotetext{
${ }^{24}$ World Bank, Finance for Growth Policy Choise in a Volatile World: A world Bank Policy Research Report (London: Oxford University Press, 2001), 17.

${ }^{25}$ Mufti membagai kebijakan ekonomi itu menjadi dua, antara lain: 1) Kebijakan pemenuhan kebutuhan pokok;

2) Kebijakan pemenuhan pokok berupa keamanan, kesehatan, dan pendidikan. Baca lebih lanjut Aries Mufti,

"UU Syariah dalam Sistem Ekonomi Islam”, FH-UI, makalah dipresentasikan pada 26 Juni 2003.

${ }^{26}$ M. Abdul Karim, Sejarah Pemikiran, 129.

27 Ibid.

${ }^{28}$ Ibid., 130.

29 Yaitu kebijakan yang dirumuskan agar pertumbuhan ekonomi membaik diimbangi dengan penurunan pengangguran dan kemiskinan yang signifikan (pemerataan).

${ }^{30}$ Konsep demokrasi ini juga pernah diterapkan oleh Rasulullah dalam rangka membangun perekonomian Kota
} 
bantuan kepada masyarakat miskin dan jaminan hidup layak yang berkecukupan kepada mereka, sangat diprioritaskan. ${ }^{31}$

Begitulah Umar ibn Abdul Aziz menerapkan semua kebijakan ekonomi dalam waktu yang relatif singkat, hanya membutuhkan waktu dua tahun setengah, namun sejarah telah mencatatnya sebagai orang brilian yang mampu mengubah keadaan terpuruk menjadi haluan yang berkeadaban dan berkemajuan.

\section{Kebijakan Ekonomi Politik Ghazan Khan}

Banyak dari kalangan sejarawan mengatakan bahwa masa awal Ghazan Khan naik tahta adalah masa yang sangat memprihatinkan, baik di bidang politik, sosial, dan ekonomi. Hal ini digambarkan secara gamblang oleh Spuler yang dikutip oleh Karim sebagai berikut: ${ }^{32}$

"When Ghazan Khan ascended the thorne, the treasures of his predecessor had been spent. The treasures that Hulagu Khan had collected from Baghdad, the provinces of the heretics (the assasins) from Syria and from other places, anf had stored in the castle, had gradually been stolen by the guards...The rest of spent by Ahmad (Tagudar)...Arghun Khan piled up many treasures. Gaikhatu did not collect any treasure, and he gave to his people what was left of the treasures of Arghun, so that Ghazan nothing."

Warisan pemerintahan sebelumnya, benar-benar menghantarkan negara (Dinasti Ilkhan) pada gerbang kehancuran. Ketika itu tidak ada laporan secara detail tentang pemasukan dan pengeluaran negara, sehingga menjadi ladang para penjabat berlomba-lomba untuk memperkaya diri sendiri. Buruknya manajemen finansial ini menyebabkan kas negara hampir kosong dan pembayaran gaji tetap para pegawai dan tentara tidak tepat waktu, bahkan sampai berbulan-bulan lamanya. ${ }^{33}$

Selain itu, masalah pemerasan pajak yang berlebihan oleh dinas perpajakan masih mengancam kesejahteraan rakyat kecil, terutama para petani. Oleh karena itu, banyak dari kalangan petani mengurungkan niatnya untuk kembali bertani lantaran takut dibebankan dengan pajak yang berlebihan. Sehingga pada gilirannya menciptakan roda perekonomian negara lumpuh total.

Setelah memahami akar persoalan di atas, maka sebagai seorang pemimpin, langkah awal dalam mengatasinya adalah dengan memberikan hukuman yang seberat-beratnya bagi siapa saja dari setiap penjabat yang menyalahgunakan tugas dan wewenang. Hasil dari penerapan langkah ini, kesejahteraan rakyat sedikit demi sedikit dapat teratasi dengan baik, begitu juga dengan masalah kas negara menjadi surplus, karena semakin derasnya pemasukan dari berbagai provinsi Dinasti Ilkhan. Umar menyadari bahwa kesinambungan antara keadilan

\footnotetext{
Madinah. Lebih lanjut baca Ayief Fathurrahman, "Strategi Rasulullah Membangun Perekonomian Madinah", makalah dipresentasikan di pasca sarjana MSI UII, 2010.

${ }^{31}$ Diriwayatkan bahwa jumlah penerima zakat terus berkurang pada masa Umar. Bahkan Para 'āmil zakat berkeliling di pelosok-pelosok Afrika untuk membagikan zakat, tapi tak seorang pun yang mau menerima zakat.

${ }^{32}$ M. Abdul Karim, Islam di Asia Tengah, 107-108.

33 Ibid. Situasi sosio-politik ini hampir serupa dengan situasi sosio-politik pada masa Dinasti Ummayah di Dimaskus pada saat Khalifah Umar ibn Abdul Aziz naik tahta.
} 
sosial dan distribusi sosial tidak akan terwujud tanpa ditopang dengan gerakan individuindividu yang bermoral tinggi.

Pada masa pemerintahannya, Ghazan mewajibkan semua gubernur dan pemungut pajak tani untuk membantu petani kecil yang tidak mampu membeli benih-benih, keperluan pertanian, dan makanan bagi ternaknya. Untuk menunjang keberhasilan pertanian, maka dibangunlah semacam lembaga informasi terpadu di berbagai provinsi mengenai segala hal yang berkaitan dengan masalah pertanian, sehingga mudah diakses dari berbagai kalangan, terutama oleh petani itu sendiri. ${ }^{34}$ Semenjak itu, produktivitas pertanian meningkat tajam, dan menjadikan hidup para petani makmur dan sejahtera.

Konsep kebijakan ekonomi yang dibangun Ghazan sangat fleksibel, tidak memudharatkan dan sangat berpihak pada rakyat. Sehingga, pada masanya, Dinasti Ilkhan menorehkan kemajuan yang luar biasa, terutama pada sektor pertanian yang mampu mewujudkan swasembada beras, sehingga dalam sejarah bangsa Mongol, khususnya Dinsati Ilkhan merupakan satu-satunya yang mampu menjadi negara pengeskpor beras ke manca negara. ${ }^{35}$

Sebagai tambahan bukti kebijakan ekonomi Ghazan yang berkarakteristik sosial, dia melarang praktek pinjam-meminjam yang mengandung bunga, karena menurutnya, inilah salah satu penyebab kesengsaraan rakyat kecil, karena praktek ini diizinkan sebelumnya sehingga menjadikan yang kaya tambah kaya, dan yang miskin pun menjadi kian melarat. Sehingga terciptalah great gap starata sosial di lingkungan masyarakat.

Pada rezimnya juga, para tentara semakin diperhatikan. Sistem yang diterapkan bukan berupa kebijakan yang mengikuti kebijakan yang diterapkan oleh Rasulullah, dan bukan pula dengan sistem yang dijalankan oleh Umar ibn Khattab, tetapi justru menggabungkan keduanya, yaitu dengan memberikan hak tanah untuk dihidupkan bagi tentara, tetapi masih tetap mendapatkan gaji tetap dari pemerintah. Alasan yang mendorong Ghazan untuk mengeluarkan dekrit ini karena adanya keinginan sendiri dari kalangan tentara, sehingga dengan cara ini menurut Ghazan, mereka dapat menyediakan keperluan mereka sendiri kaitannya dengan kemiliteran, seperti penanggung kuda dan hewan-hewan lainnya. Selain itu, pada masanya ekspansi wilayah tidak terlalu diprioritaskan.

Sebuah reformasi ekonomi politik telah terjadi di Dinasti Ilkhan di bawah komando Ghazan Khan yang membawa Dinasti Ilkhan bergerak menuju kesejahteraan rakyat dan mewujudkan kembali kejayaan. Keamanan negara sangat terjamin, bahkan digambarkan layaknya "rusa merasa aman ketika satu tepi bersama harimau". Sepeninggalnya, pemimpin yang sangat dicintai oleh rakyat ini mewarisi kondisi keuangan negara sangat surplus, dan perkonomian yang sangat stabil.

Demikianlah beberapa kebijakan ekonomi yang dikeluarkan oleh Ghazan Khan. Dia berhasil membalik keadaan negara, yang awalnya negara sangat defisit anggaran, namun semenjak dia naik tahta, negara pun mengalami surplus anggaran, sehingga memberikan kesejahteraan dan kemakmuran bagi warga negaranya.

\footnotetext{
${ }^{34}$ Ibid., 109.

${ }^{35}$ Ibid., 110.
} 


\section{Korelasi Pemikiran dan Relevansinya dengan Kekinian}

Sebagaimana penjelasan di atas, nampak jelas bahwa kebijakan ekonomi yang dikeluarkan oleh Umar ibn Khattab, Umar ibn Abdul Aziz, dan Ghazan Khan mempunyai karakter yang fleksibel dan tidak kaku. Artinya, apapun caranya asalkan bertujuan untuk menciptakan kesejahteraan rakyat dan selama tidak bertentang dengan al-Quran dan alSunnah, maka kebijakan itulah yang diterapkan. Hal ini terlihat jelas ketika beberapa kebijakan mereka tidak selalu sama dengan kebijakan pada masa Rasulullah, bahkan saling berbeda satu sama lain, namun justru di dalam perbedaan itulah dunia telah mencatat mereka sebagai decision maker yang brilian.

Selain itu, kebijakan ekonomi mereka sangat berdimenasi sosial yang berkeadilan, yang sama-sama menyisihkan ruang khusus (partial treatment) untuk pertolongan bagi komunitas yang kerap kali dinomorduakan, terutama kaum-kaum yang tergolong miskin dan tidak punya kemampuan. Ruang khusus ini dimaksudkan sebagai upaya untuk mewujudkan kesetaraan di kalangan pelaku aktivitas ekonomi, sehingga pembangunan di segala aspek untuk menunjang taraf hidup masyarakat terealisasikan dengan pemerataan yang efektif. Partial treatment ini berangkat dari nilai-nilai qurani yang memerintahkan manusia untuk saling membantu satu sama lain untuk menggalang sebuah kesejahteraan dan menata suatu kemakmuran, dan membuang sifat keserakahan. ${ }^{36}$

Bukankah pembangunan tidak dapat dilakukan tanpa keadilan, yakni keadilan dalam semua sektor kehidupan. Keadilan yang komprehensif ini tidak akan terwujud tanpa penciptaan masyarakat yang peduli lewat persaudaraan dan persamaan sosial, dan terjaminnya keamanan kehidupan.

Variabel yang sangat berperan dalam hal ini adalah pemerintah. Ketiga khalifah sebagai kepala pemerintahan di atas sangat memahami dan mengamalkan dalam segala kebijakan yang diputuskan, sehingga mengokohkan sendi-sendi keadilan, dan berbuah pada kesejahteraan dan kemakmuran rakyat. Jalan berbeda, bukan berarti tujuan juga berbeda, karena dalam urusan muamalah yang menjadi pertimbangan utama adalah asas kemanfaatan bagi masyarakat dan kesejahteraan. Inilah konsep rạ̣matan li al-‘̄amīin, yang membawa rahmat bagi semesta alam.

Berkaitan dengan penjelasan di atas, ada fenomena menarik untuk dikaji secara mendalam tentang pemikiran ekonomi Islam, terutama pada ranah kebijakan yang dikeluarkan oleh ekonom muslim. Dewasa ini, memang tak bisa dipungkiri bahwa perkembangan lembaga ekonomi Islam telah mengukir prestasi di catatan sejarah. Hal ini merupakan tuntutan realitas keadaan masyarakat yang memerlukan struktur perkonomian yang baru, karena struktur perekonomian yang ada sudah menjadi sembilu yang selalu menusuk bangunan perekonomian, baik dalam skala lokal, regional maupun internasional.

Namun seiring dengan perkembangannya, nilai-nilai dasar Islam berupa kesejahteran dan kemakmuran yang seharusnya mendampingi perjalanan ekonomi Islam, kini hubungan keduanya menunjukkan tanda-tanda ketidakharmonisan. Kadang-kadang ketidakhrmonisan itu berupa batasan-batasan ekstrim yang sangat "islami", walaupun menurut berbagai ahli itu sangat berpotensi untuk mendulang kesejahteraan untuk semua. Sehingga pada gilirannya

\footnotetext{
${ }^{36}$ Pandangan ini dapat dilihat pada al-Quran, 49:10, dan $t a{ }^{\prime}$ âw $5: 3$.
} 
menghambat laju pertumbuhan ekonomi Islam itu sendiri. ${ }^{37}$ Dan kadang-kadang ketidakharmonisan itu berupa kebijakan tanpa dasar syar'i, yang seenaknya menabrak batasan-batasan syar'i demi meraup keuntungan, yang pada akhirnya ekonomi Islam hanya dibatasi dengan sebuah dinding tipis dan "transparan" dengan sistem kapitalisme maupun sosialis.

Ketidaktahuan tentang tujuan diterapkannnya sistem ekonomi Islam akan berakibat fatal, bahkan bisa merubah nilai-nilai yang ada pada bangunan sistem ekonomi Islam itu sendiri. Islam itu mudah, tapi jangan terlalu dipermudah. Ada garis-garis syar'i yang harus dipatuhi, namun jangan juga mensakralkan "fikih klasik" yang seolah-olah haram untuk dirubah, sementara zaman sudah berubah. Kebenaran doktrin fikih pada dasarnya adalah bersifat nisbi (relatif) dan sangat dipengaruhi oleh dimensi ruang dan waktu saat fikih dibuat. $^{38}$

Faktanya, baik al-Quran maupun al-Sunnah tidak pernah benar-benar dijadikan landasan dalam menerapkan secara menyeluruh di dalam penerapan praktek ekonomi Islam itu sendiri. Justru fikih yang sekedar hasil rasionalisasi kreatif ulama dijadikan sebagai acuan utama. Hal ini tampak jelas dalam berbagai produk transaksi yang ditawarkan perbankan Islam sebagai lokomotif gerakan ekonomi Islam, di mana hampir semua merujuk pada jenis-jenis transaksi kontrak dalam fikih klasik. ${ }^{39}$

Hal ini perlu dipertimbangkan, karena baik kaidah fikih maupun ushul fikih dalam batas tertentu tidak akan mampu memecahkan problem kontemporer. ${ }^{40}$ Oleh karenanya, agar metode itu compatible dengan dunia modern, maka perlu ada pengembangan metodologi, yang tentunya sesuai dan selaras dengan perkembangan, kemajuan dan dinamika dunia modern.

Keyakinan akan ketidaksempurnaan metode ilmiah Barat dalam membangun aspek kehidupan, ${ }^{41}$ seharusnya diejawantahkan melalui dinamisasi pemikiran atau aturan-aturan "islami”, yang selama ini masih dirasa mandul dalam merespon isu-isu kontemporer. Banyak

${ }^{37}$ Gerakan islamisasi ilmu ekonomi, pada akhirnya diarahkan oleh kepentingan politik-ekonomi tertentu. Ia bergeser ke arah perjuangan politik-ekonomi sectarian. Ekonomi Islam dibangun dan dikembangkan demi kepentingan "umat Islam". Bukan lagi murni sebagai gerakan intelektual yang memihak kepada kebenaran itu sendiri ataupun untuk mengabdi pada kemanusiaan secara lebih luas. Baca Yusdani, "Islamisasi Model al-Faruqi dan Penerapannya dalam Ilmu Ekonomi Islam di Indonesia (Suatu Kritik Epistemik)" dalam La Riba, Vol. I, No. 1 (Juli, 2007).

${ }^{38}$ Muhammad Amin Suma, "Tinjauan Fiqh Islam Terhadap Yurisprudensi Peradilan agama dari Pelaksanaan Undang-Undang Peradilan Agama", Dalam Laporan Seminar 10 Tahun Undang-Undang Peradilan Agama; Kerjasama DITBAPERA-Islam, Fakultas Hukum UI, dan Pusat Pengkajian Hukum Islam dan Masyarakat, , (Jakarta: Chasindo, 1989), 63.

${ }^{39}$ Ayief Fathurrahman, "Meninjau Ulang Landasan Normatif Perbankan Syariah di Indonesia: Telaah atas Teori Kontruksi Fikih Klasik", Makalah Pasca Sarjana MSI UII, 2010.

${ }^{40}$ Menurut suhartono, belum adanya standarisasi atau keseragaman landasan hukum fikih klasik memunculkan adagium "different judge different sentence" yang berujung terjadinya putusan yang berdisparitas tinggi, dalam perspektif teori hukum positif, hal ini berbenturan dengan prinsip kepastian hukum. Baca lebih lanjut Suhartono, "Penggunaan Fikih Muamalah Sebagai Dasar Penyelesaian Sengketa Ekonomi Syari'ah Di Pengadilan Agama (Suatu Kajian Dalam Perspektif Asas Hukum)" dalam http://www.badilag. net.

${ }^{41}$ Sebagaimana dijelaskan oleh Louay Safi, metode Barat memiliki sejumlah kekurangan, pertama, metode yang direngkuh sarjana-sarjana Barat menghasilkan hukum dan teori yang bias. Kedua, sarjana Barat secara sempurna menyingkirkan wahyu sebagai suatu sumber pengetahuan, dan dengan demikian telah mereduksi wahyu pada tingkat semata-mata sebagai khayalan dan dongeng. Baca lebih lanjut Louay Safi, Rancangan Metodologi Alternatif: Sebuah Refleksi Perbandingan Metode Penelitian Islam dan Barat, terj. Imam Khoiri (Yogyakarta: Tiara Wacana, 2001), 10. 
sudah contoh ketimpangan metode ilmiah Barat terhadap aspek kemanusiaan. Dalam bidang ekonomi misalnya, sistem kapitalisme yang selama ini merajai panggung jagat raya perekonomian international telah menciptakan kehancuran pondasi struktur perekonomian global. Pada tahun 2008, depresi kembali melanda sistem perekonomian dunia. Banyak dari berbagai kalangan menilai bahwa krisis keuangan global merupakan bukti gagalnya sistem ekonomi kapitalis.

Dalam konteks kemajuan dan perkembangan ekonomi Islam, ekonom muslim seharusnya menciptakan sistem ekonomi yang tidak kaku dan menjadikan kesejahteraan dan kemakmuran sebagai landasan awal operasionalisasi dan perumusan sistem ekonomi Islam. Sehingga pada gilirannya, sentuhan ekonomi Islam terhadap masyarakat akan terasa bukan saja di kalangan kaya ataupun miskin saja, tetapi semua pelaku aktivitas ekonomi di muka dunia ini.

\section{Kesimpulan}

Satu hal yang kiranya perlu dipahami, adalah bahwa setiap hasil pemikiran manusia, selalu bersifat historis; terikat dengan ruang dan waktu yang mengitarinya. Kebijakan ekonomi yang dikeluarkan oleh Umar ibn Khattab, Umar ibn Abdul Aziz, dan Ghazan Khan, tentulah memiliki kebenaran-kebenaran tertentu sesuai dengan dimensi ruang dan perputaran waktunya. Bagaimanapun bentuknya, kebijakan tersebut merupakan sebuah upaya solusi terhadap berbagai problema negara, terutama sektor perkonomian yang terjadi di tengah masa bakti kepemimpinan meraka.

Kebijakan ketiga khalifah di atas mengajarkan kita, terutama para penentu akhir kebijakan ekonomi sebuah makna kesejahteraan (mașlaḥah) yang menjadi dasar pijakan perumusan satu kebijakan. Sistem ekonomi yang kaku hanya akan menjadi sebuah bomerang tersendiri bagi pertumbuhan ekonomi itu sendiri. Karena sejatinya yang menjadi tujuan suci ekonomi adalah bukan pertumbuhan ekonomi, melainkan kesejahteraan umat manusia sebagai pelaku aktivitas ekonomi di belahan bumi ini.

\section{Daftar Rujukan}

Afzalurrahman. Doktrin Ekonomi Islam, Jilid 1. Yogyakarta: PT Dhana Bakti Wakaf, 1995.

Fathurrahman, Ayief. "Strategi Rasulullah Membangun Perekonomian Madinah", makalah dipresentasikan di pasca sarjana MSI UII tahun 2010.

"Meninjau Ulang Landasan Normatif Perbankan Syariah di Indonesia: Telaah atas Teori Kontruksi Fikih Klasik", Makalah Pasca Sarjana MSI UII tahun 2010.

Hakim, Latif. "Strategi Umar Ibn Abdul Aziz dalam Mengentaskan Kemiskinan", dalam http://zulfikri.wordpress.com/strategi-umar-ibn-abdul-aziz-dalam-mengentaskankemiskinan/ diakses pada 2007.

Isamer, Ali. Itihash. Dhaka: Ali Publication, 1976.

Husaini, S. A.Q. Arab Adminitration. Madras: Soldent \& Co, 1949.

Karim, Adiwarman Azwar. Sejarah Pemikiran Ekonomi Islam, edisi ketiga. Jakarta: PT Raja Grafindo Persada, 2004.

Karim, M. Abdul. Sejarah Pemikiran dan Peradaban Islam. Yogyakarta: Pustaka Book Publisher, 2007. 
. Islam di Asia Tengah: Sejarah Dinasti Mongol-Islam. Yogyakarta: Bagaskara, 2006.

Mufti, Aries. UU Syariah dalam Sistem Ekonomi Islam, Makalah FH-UI, 26 Juni 2003.

Muhammad, Qutbh Ibrahim. Kebijakan Ekonomi Umar ibn Khattab. Jakarta: Pustaka Azam, 2002.

Nasution, Harun. Islam Ditinjau dari Berbagai Aspeknya, jilid 1, cet. 5. Jakarta: UI Press, 1985.

Safi, Louay. Rancangan Metodologi Alternatif: Sebuah Refleksi Perbandingan Metode Penelitian Islam dan Barat, terj. Imam Khoiri. Yogyakarta: Tiara Wacana, 2001.

Suma, Muhammad Amin. Tinjauan Fiqh Islam Terhadap Yurisprudensi Peradilan agama dari Pelaksanaan Undang-Undang Peradilan Agama, dalam Laporan Seminar 10 Tahun Undang-Undang Peradilan Agama Kerjasama DITBAPERA-Islam, Fakultas Hukum UI, dan Pusat Pengkajian Hukum Islam dan Masyarakat Jakarta tahun 1989.

Suhartono. "Penggunaan Fikih Muamalah Sebagai Dasar Penyelesaian Sengketa Ekonomi Syari'ah di Pengadilan Agama (Suatu Kajian Dalam Perspektif Asas Hukum), dalam http://www.badilag. Net.

World Bank. Finance for Growth Policy Choise in a Volatile World: A World Bank Policy Research Report. London: Oxford University Press, 2001.

Yatim, Badri. Sejarah Perdaban Islam: Dirasah Islamiyah II. Jakarta: PT Raja Grafindo Persada, 2003.

Yusdani. "Islamisasi Model al-Faruqi dan Penerapannya dalam Ilmu Ekonomi Islam di Indonesia (Suatu Kritik Epistemik)”, dalam La Riba, Vol. I, No. 1, Juli 2007. 